\title{
Research on the Strategy of Human Resources Management for Non- profit Organizations
}

\author{
Yun-Yan KAN \\ School of Business Administration. NanChang Institute of Technology \\ NanChang Institute of Technology, NIT \\ Nanchang City, Jiangxi Province, China \\ 376302633@qq.com
}

Keywords: Human resources Management, Nonprofit organizations, Strategy

\begin{abstract}
The article defined human resources management for nonprofit organizations and described the characteristics of it. Then the author analyzed the main problems in the human resources management for nonprofit organizations. Finally, based on the above analysis, the author discussed the main measures of managing human resources management for nonprofit organizations. The article is of great help to provide some ideas of managing nonprofit organizations employees.
\end{abstract}

\section{Introduction}

Government organizations, for-profit and nonprofit organizations constitute three major components of a political, economic and social sphere in modern society.

Human resource management is not only applicable to for-profit organizations, its spirit and approach also apply to government departments and nonprofit organizations. Human resource management in nonprofit organizations is an integral part of society as a whole in the human resource management system, and it is also an important part of nonprofit organization management system as a whole. Especially in recent years, nonprofit organization human resource management researches are great significance to our country development.

\section{The Meaning and Nature of Nonprofit Organizations}

\section{Meaning of Nonprofit Organizations}

"Nonprofit organization" emphasized the organization exists not only for the purpose of profit. But note that "not for profit" does not mean that the organization is "no profit", In fact, the income of nonprofit organizations is often greater than the expenditure, in other words, they are profitable. Defined on it, now there are four more influential: First, gives the legal definition. Many countries in the world have special legal requirements on the third sector organizations. Such as the United States, There are clear provisions to tax exempt from federal income tax of the third sector in the tax law. Organizations subject to these articles may fall into the third sector. Because of the different national laws, this definition may be very accurate within the scope of a nation, but it's hard to compare to other countries. Second is to be defined based on the capital source of organizations. The national income of the United Nations system is such a definition. The system of all economic activity is divided into five broad categories: financial institutions, non-financial institutions, governments, nonprofit organizations, families. The difference between nonprofit organizations and other social organizations is that their revenue is not from selling goods and services at market prices, but from contributions paid by its members and donations from supporters. According to this definition, each country will have its own definition of the nonprofit sector.

To sum up, a nonprofit organization in this article is not for profit-making purposes. It is all of non-government organizations outside of governments and profit-making enterprises. On the extension, it includes societies, private non-enterprise units, the State-owned institutions, mass organizations, and other organizations (such as societies inside the unit, in the form of enterprise registration and unregistered, etc). 


\section{Particularity of Human Resource Management in Nonprofit Organizations}

With the development and progress of society, human resources has become the most important social productive resources. Therefore, organizations are starting to pay attention to talents training and accumulation. However, in the nonprofit organization, responsibilities of human resource departments are still seemed to remain in the original responsibilities of organizational management. In fact, the nonprofit organizations mainly means professional organizations. It's not only human resource management in the general sense, and also has the special nature determined by its own characteristics, and nonprofit organizations human resource management will have a special mission with it. The special nature of human resources in nonprofit organizations determined the nonprofit organization of human resources management has the following particularities.

\section{Particularities of Quality Requirements}

As a nonprofit organization is not for profit-making purposes, and is an independent institution for social public interest or service, members of the nonprofit organization qualities have particular requirements, that is human resources in nonprofit organizations have higher political consciousness and moral qualities than the average level of society as a whole. In a nonprofit organization, leadership, planning, management, administration and other activities should have a high degree of voluntary participation component, and a very strong team spirit among the members, and individual members should have a higher ethical self-discipline. Therefore, it has a high sense of social mission, therefore, how to make the volunteer maintain a high sense of mission is another challenge for nonprofit organization. The difficulty was particularly acute in the process of transition from a planned economy to a market economy in China today.

Peter Drucker believe that it has often been said in the past, volunteers are not paid, so not too high demands on them, but this view has been changed now, because they are not salaried, volunteers will get greater satisfaction from their achievements, and make greater achievements. Hesaierben believe that institutions, should believe that each volunteer is a valuable, venerable and equal individual, and their leader. To volunteer, doing volunteer work must be constantly learning and growing process, so that they can maintain the enthusiasm and creativity.

\section{Particularities of Incentives}

In our country, nonprofit organizations generally lack of funds needed for development. In a large extent, the nonprofit sector is a way split apart from government to obtain civil resources, rather than accept government funding, entrusted by the government to implement the project's tools. China's regulations on public donation have three, first introduced in 1999 the People's Republic of China public welfare donations Act; Second on March 13, 2001 issued by the Ministry of finance and the State administration of taxation the notice on the perfection of social security system in cities and towns in the pilot on tax policy issues; Third in January 2001 published by the People's Republic of China Ministry of finance, the State administration of taxation and the People's Republic of China Customs interim measures for poverty alleviation, the nonprofit donated materials free of import taxes. Because there are no specific rules for the implementation, examples are very rare. The notice issued by the Ministry of finance and the State administration of taxation just provides that in implemented social security system reform pilot of province, autonomous region and municipalities, public, relievable donations From enterprises, institutions, social organizations and individuals to nonprofit organizations, foundations, and other nonprofit institutions are granted full deduction before the payment of corporate income tax and personal income tax. This notice is only a small range of pilot programmes far from being implemented throughout the country. From the pilot provinces, few performers are in accordance with the notice provisions. Company and personal donation behavior do not increase significantly. This is not only because of the provision are not very under- 
standing, but more important is that the pilot region finance and tax departments are not necessarily in accordance with provisions of the notice. Interim measures for poverty alleviation, the nonprofit donated materials free of import taxes proposed that donated material from foreign donors free to recipients directly for poverty alleviation and nonprofit business is exempted from import tariffs and import-linked value added tax. This is only a fraction of the funds needed for development of nonprofit organization.

Generally speaking, China's nonprofit sector generally faces financial difficulties. Funds are precondition for a nonprofit organization to implement projects, and also important factors caused general lack of economic incentive in nonprofit organizations, and this have decided the particularities of incentive differently between nonprofit organizations and profit organizations.

\section{Particularities of Performance Evaluation}

Human resources performance evaluation for nonprofit organizations are different from organizations in general, mainly in: performance evaluation is not necessarily directly linked to the material incentive; In the performance evaluation process, methods of qualitative are generally more than quantitative methods; Evaluation for employee contributions should not look the short term gains, but to look at the long term contribution. Nonprofit organizations lack of three kinds of responsibility mechanism in enterprises may cause inefficiency and under power. First, the lack of personal interest: general business are private, corporate interests are also personal interests that ensure responsible person pay attention to efficiency, not to seeking too high benefits for individuals and employees. Secondly, the lack of mechanism of competition to enhance efficiency: most nonprofit organizations are almost monopolized, such as public schools and public hospitals. The lack of competition lead to the lack of pressure and power to increase nonprofit organizations efficiency. Third, the lack of showing business performance indicators-profit.

As mentioned above, the problem exists in both the first and second sectors in many developing countries, China as well. Therefore, the third sector relies on "forced charity" sector is not terrible, as long as this force provide the "public welfare" rather than private benefits. Similarly, the third sector relies on "voluntary private interest" mechanisms are also not terrible, as long as it is provided through voluntary rather than mandatory.

\section{Problems in the Human Resource Management of Nonprofit Organizations}

For a Long time, management was seen as a "profit" means that are closely related. Nonprofit organization is not intended to profit, and management is not required. Therefore, most of the nonprofit organization focuses management on the Organization of material resources and financial resources, rather than on human resources management. The previous chapters show the particularity of human resource management for nonprofit organizations. On the present situation of human resource management in nonprofit organizations there are many different levels of management problems in a period of economic transition in China.

\section{Serious Lack of Human Resources Talents in Nonprofit Organizations}

Particularity of the nonprofit organization proposes high quality requirements for the staff and increases the difficulty of nonprofit organizations recruiting suitable staff. Nonprofit organization uses public resources, and provides public goods. Therefore, the staff behavior is monitored by the organization, and be accountable to the public. These require employees of nonprofit organizations not only have strong professional qualities, but also have high ethical standards and strong dedication. At the same time, nonprofit organization is not for profit-making purposes. Its inherent driving force is not the profit motive and powerful principles, but the altruism and solidarity in volunteerism background, shouldering the social "mission", so as to obtain approvals and supports from all sides. So 
the most important features of nonprofit organizations is mission. It represents responsibility, public and faith of organizations, and as nonprofit organization's action guiding, even represents the value of nonprofit organizations. This allows the staff of nonprofit organizations must always keep in mind the responsibility and faith, and performance at work, creating and maintaining a nonprofit organization a good social reputation and image. This increases the pressure on staff, and also increases the difficulty of nonprofit organizations recruiting suitable staff.

\section{Insufficient Development and Utilization of Human Resources Management in Nonprofit Organizations}

Many nonprofit organizations lack specifical talent training mechanism, and human resources level does not progress obviously. Human resources need development and cultivation, so to full play people potential, and people have more requirements on nonprofit organization service quality and type and staff skills. All of this force nonprofit organization to take active implementation on training and personal development plans to improve members' quality and ability, and to deal with various environment challenges. However, many nonprofit organizations either neglect to train or fail to provide opportunities for training due to lack of funding and labor force. The nonprofit organization lack of talent training can not promote human resources level, even behind other groups, and make internal organizations lack of vitality and creativity.

At the same time, nonprofit organizations lack of the effective management of volunteers, and employees of the nonprofit sector contains a large number of volunteers. Management on volunteers is the largest difference between a nonprofit organization human resource management and enterprise human resource management, and is also one of the most distinctive aspects in nonprofit organization human resource management, but it has also brought challenges to the nonprofit organization. Nonprofit organizations must have a complete and clear volunteers management planning to take advantage of volunteer resources, such as volunteer recruitment, training, motivation, assessment, protection and so on. However, nonprofit organizations in our country have not done enough, and many related education, training, volunteer opportunities are limited. This will inevitably lead to some volunteers with real life passion lack of understanding of the organization and work, and relevant work experience, and can't handle the work.

\section{Serious Human Resources Flow Phenomenon In Nonprofit Organizations}

On the nature of nonprofit organizations, The people who have a sense of mission and don't care about reward are qualified for nonprofit organizations work. But with the economic and social development, material life to employees of nonprofit organizations must have some effects. Many nonprofit organizations often overlook material incentives to employees, only relying on traditional spiritual incentive that make many employees waver in planing for longer-term work in the nonprofit organizations under the pressure of work.

At the same time ,a large number of professionals in the nonprofit organization belong to knowledge workers, who highly value whether the nonprofit organization provides opportunities for intellectual growth, self development. As nonprofit organizations can not provide appropriate opportunities for learning and training, members will probably lack of original trust and loyalty for the organizations because of failure to meet individual needs on self learning, self improvement and self-perfection. So some people are likely to flow to for-profit organizations, resulting in loss of talent. Again, employees of nonprofit organizations, especially the volunteers of the inadequate social security system, also led directly to the loss of human resources in nonprofit organizations. The full-time staff of social security cannot be realized, and cannot solve the looking back in many nonprofit organizations in our country due to lack of funds and lack of preparation. 


\section{Main Strategies of Human Resource Management in Nonprofit Organizations}

Because of a large number of issues in our nonprofit organization human resources management, it lead a nonprofit organization lack of capacity for effective management of available resources and the potential for further development, that directly constrains the further development of the nonprofit organizations in China. This requires that governments, nonprofit organizations, society, and citizens work together to take practical measures to address them

\section{Improving Nonprofit Organization Human Resources Management Recruitment}

Talent is a nonprofit organization most valuable resource, so the recruitment and selection of personnel is the first level related to the survival and development of the organization. Organizations should provide performance opportunities and resources for motivated staff to reach this achievement. Nonprofit organizations must strengthen management in the recruitment process to obtain and absorb the excellent human resources. For the recruitment of excellent talents, we should adopt the appropriate policies such as recruitment time select, and channel select on the recruitment management, so as to improve the efficiency, and attract high level and qualified talent. More members of nonprofit organizations are volunteers with full freedom, so in addition to emergency personnel in recruitment time, more is needed from time to time to recruit outstanding talent as a reserve cadre. In general, recruitment channels can be divided into internal and external. Different channels have specific ways of recruitment. Internal recruitment adjusts the nonprofit human resources within an organization through the recruitment of internal excellent talents. External recruitment make more choice in the major colleges, universities, industry associations, as well as personnel of special groups, conducive to the nonprofit organization to recruit top talent, bringing new ideas and methods for the organization.

\section{Standardizing Human Resource Management System}

A perfect system of human resources management can be established according to western developed countries mature nonprofit human resources management system, and the actual situation in China. In China, there is extreme lack of professional talents in nonprofit organizations, so to address the root of the problem is to develop a professional training, and then to achieve "Ant effect". "Ant effect" advantage in concentrated form is that- can quickly adjust according to the environmental changes; Tough - individual weaknesses, and cannot affect the efficient operation of the overall; self organization--not too much control from top to botton to complete themselves. Ant effect can defer the lack of professional pressures. It is undoubtedly the dreams of organizations in the development of modern enterprises. Human resource management of nonprofit organizations in China should be people-oriented management. It is consistent with "people-oriented" advocated by harmonious society and can also solve the problem of mobility.

\section{Establishment of Effective Incentive Mechanism}

Material is indispensable in the process of constraints and incentives for members, but more important is targeted incentives, people management, culture construction and flexible management. Nonprofit organizations can set a target through advocating organizations' culture to agglomerate individuals together, and promote and constraint individual behavior by organizational behavior, raising the individual sense of responsibility and mission, and the masses ' sense of identity so that members feel their own worth. In nonprofit organization, manager should put forward objectives, guidelines, and to lead, persuade, encourage employees, inspiring their inner motivation. 


\section{Summary}

As nonprofit organizations have their particular nature and characteristics, so it needs systemic thinking, model development, solutions, and implementation while engaged in human resource development of the nonprofit organizations. In the development of the nonprofit organizations, its human resource management should analyze their own human resource situation, characteristics, strengths and weaknesses and environmental impacts while learning from enterprises, establishing a unique model of their human resource development. In practice, it will achieve maximum results with little effort combining with characteristics of nonprofit organizations, and suming up existing experiences. Strategic in the implementation needs specific programmes, only every programme, every link, every detail has a person in charge that can ensure implementation in place. Problems faced by nonprofit organizations can be effectively resolved in the development, and it can create good growth for nonprofit organizations development.

\section{References}

[1] Josephson B W, Johnson J L, Mariadoss B J. Strategic marketing ambidexterity: antecedents and financial consequences[J]. Journal of the Academy of Marketing Science, 2016, 44(4): 539-554.

[2] Madsen P M, Rodgers Z J. Looking good by doing good: the antecedents and consequences of stakeholder attention to corporate disaster relief[J]. Strategic Management Journal. 2015, 36(5): 776-794 .

[3] Lin Y, Wu L Y. Exploring the role of dynamic capabilities in firm performance under the resource-based view framework[J]. Journal of Business Research, 2014, 67(3): 407-413.

[4] Makkonen H, Pohjola M, Olkkonen R, et al. Dynamic capabilities and firm performance in a financial crisis[J]. Journal of Business Research, 2014, 67(1): 2707-2719.

[5] McWilliams A, Siegel D S. Creating and capturing value: strategic corporate social responsibility, resource-based theory and sustainable competitive advantage [J]. Journal of Management, 2011, 37(5): 1480-1495.

[6] McWilliams A, Siegel D S. Additional reflections on the strategic implications of corporate social responsibility[J]. Academy of Management Review, 2002, 27(1): 15-16.

[7] Peteraf M, Stefano G D, Verona G. The elephant of the room dynamic capabilities: bringing two diverging conversations together[J]. Strategic Management Journal,2013, 34(12):1389-1410.

[8] Porter, M E, Kramer M R. Strategy and society: The link between competitive advantage and corporate social responsibility. Harvard Business Review, 2006, 84(2), 78-93.

[9] Ramachandran V. Strategic corporate social responsibility: a 'dynamic capabilities' perspective[J]. Corporate Social Responsibility and Environmental Management. 2011, 18: 285-293 . 